\title{
EVALUASI IMPLEMENTASI APLIKASI PRIMARYCARE (PCARE) GUNA MENUNJANG PENGKLAIMAN BPJS DI KLINIK DR. ALFRED MAJALAYA
}

\author{
Dwi Nur Inayah Sari ${ }^{1}$, Trisi Rahil Maulvi ${ }^{2}$, Syaikhul Wahab ${ }^{3}$ \\ Politeknik Piksi Ganesha Bandung, Indonesia ${ }^{1,2,3}$ \\ dwinurinayahsari618@gmail.com ${ }^{1}$, trisimaulvi12@gmail.com², \\ syaikhulwahab@gmail.com ${ }^{3}$
}

Received: 16-07-2021

Revised : 17-11-2021

Accepted: 18-11-2021

\begin{abstract}
Abstrak
Latar Belakang: Semakin meningkatkan jumlah peserta BPJS tentunya dibutuhkan sebuah sistem informasi yang dapat menunjang pelayanan di sebuah fasilitas kesehatan, sehingga pada tahun 2014 BPJS mengeluarkan sebuah sistem informasi yang bernama aplikasi Pcare untuk pelayanan kesehatan pertama.
\end{abstract}

Tujuan: Penelitian ini bertujuan untuk mengevaluasi implementasi aplikasi Primary Care (Pcare) Guna Menunjang Pengklaiman BPJS di Klinik Dr.Alfred Majalaya Metode: Jenis Penelitian ini adalah deskriptif dengan pendekatan kualitatif. Rancangan penelitian yang digunakan adalah studi kasus. Subject penelitian ini adalah petugas Rekam medis dan petugas Farmasi.

Hasil: Penelitian ini telah dilakukan sejak mulai April 2021 sampai dengan Juni 2021. Validitas data yang digunakan adalah menggunakan triangulasi sumber dan teknik. Aplikasi Pcare telah digunakan di Klinik Dr.Alfred Majalaya sejak tahun 2019 akan tetapi masih sering terjadi error dan loading lama, sistem kontrol yang digunakan telah menggunakan username dan password namun masih ada pihak yang tidak mempunyai wewenang yang dapat mengakses dan menggunakan aplikasi Pcare, dan penggunaan sumber daya (material dan manusia) telah sesuai dengan kebutuhan. Aplikasi Pcare telah digunakan di Klinik Dr.Alfred Majalaya sejak tahun 2019, namun masih ada beberapa masalah yang belum terselesaikan.

Kesimpulan: Kinerja aplikasi Pcare di Klinik Dr.Alfred Majalaya masih sering mengalami error dan loading lama. Cara pengendalian (control) Pcare di Klinik Dr.Alfred Majalaya menggunakan user name, password, antivirus dan anti hacker. Adanya petugas yang tidak mempunyai wewenang yang dapat mengakses dan menggunakan aplikasi Pcare.

Kata kunci: evaluasi; implementasi; aplikasi primary care (Pcare).

\section{Abstract}


Background: Increasing the number of BPJS participants, of course, requires an information system that can support services at a health facility, so in 2014 BPJS issued an information system called the Pcare application for the first health service.

Objective: This study aims to evaluate the implementation of the Primary Care (Pcare) application to Support BPJS Claims at the Dr.Alfred Majalaya Clinic.

Methods: This type of research is descriptive with a qualitative approach. The research design used is a case study. The subjects of this study were medical record officers and pharmacists.

Results: This research has been conducted since April 2021 until June 2021. The validity of the data used is using triangulation of sources and techniques. The Pcare application has been used at the Dr.Alfred Majalaya Clinic since 2019 but there are still errors and long loading times, the control system used has used a username and password but there are still parties who do not have the authority to access and use the Pcare application, and use the Pcare application. resources (material and human) have been in accordance with the needs. The Pcare application has been used at Dr. Alfred Majalaya Clinic since 2019, but there are still some unresolved problems.

Conclusion: The performance of the Pcare application at the Dr.Alfred Majalaya Clinic still often experiences errors and takes a long time to load. How to control Pcare at Dr.Alfred Majalaya Clinic using a username, password, antivirus and anti-hacker. There are officers who do not have the authority to access and use the Pcare application. Keywords: evaluation; implementation; primary care app (Pcare).

${ }^{*}$ Correspondent Author: Dwi Nur Inayah Sari Email: dwinurinayahsari618@gmail.com

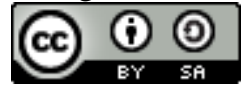

\section{PENDAHULUAN}

Sosial kesehatan atau sering disebut BPJS Kesehatan merupakan semua badan hukum yang dibentuk untuk menyelenggarakan program jaminan sosial kesehatan di Indonesia (Suprianto \& Mutiarin, 2017). BPJS kesehatan dibentuk untuk meningkatkan derajat kesehatan masyarakat indonesia sehingga hak warga negara Indonesia untuk mendapatkan pelayanan kesehatan dapat terpenuhi. Hak warga negara Indonesia untuk mendapatkan pelayanan yang layak juga telah tercantum di dalam Undang-Undang Negara Republik Indonesia tahun 1945 pasal $28 \mathrm{H}$ ayat satu yang berbunyi setiap orang berhak hidup sejahtera lahir dan batin, bertempat tinggal dan mendapatkan lingkungan hidup yang baik dan sehat serta berhak memperoleh pelayanan kesehatan (Perundangundangan, 1945). Atas dasar itulah pemerintah tahun 2019 mewajibkan semua masyarakat Indonesia telah terdaftar dan menjadi anggota BPJS termasuk warga negara asing yang telah bekerja yang lebih dari 6 bulan di Indonesia (Universal Health Coverage) (Wariyanti, Suryono, \& Indarto, 2016).

Evaluasi Implementasi Aplikasi Primarycare (Pcare) Guna Menunjang Pengklaiman BPJS di Klinik Dr. Alfred Majalaya 
Berdasarkan data pusat pembiayaan dan jaminan kesehatan Kementerian Kesehatan jumlah tahun 2017 yang sudah mendaftar menjadi peserta BPJS kesehatan mengalami kenaikan dari tahun 2014, 2015, dan 2016. Tahun 2014 jumlah peserta yang terdaftar sebanyak 13,423,653 peserta, tahun 2015 jumlah peserta terdaftar sebanyak 156,790,287, dan pada tahun 2016 jumlah peserta terdaftar sebanyak 171,677,176 (Susanti, Rinawan, \& Amelia, 2019).

Berdasarkan data sekunder yang di dapati oleh peneliti terhadap aplikasi Pcare di Klinik Dr.Alfred Majalaya yang sudah mendaftar menjadi peserta BPJS kesehatan mengalami kenaikan pada bulan April-Juni 2021 jumlah peserta terdaftar sebanyak 560 peserta.

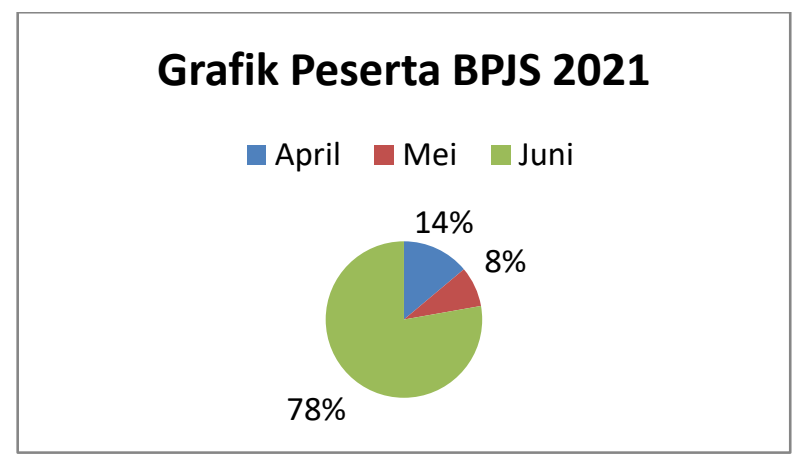

Hal tersebut juga diikuti dengan meningkatnya fasilitas Kesehatan Tingkat Pertama ( FKTP ) yang menjalin bekerja sama dengan JKN (BPJS kesehatan), terbukti pada tahun 2014 ada sebanyak 18.437 FKTP yang telah bekerjasama dengan JKN (BPJS kesehatan), tahun 2015 ada sebanyak 19,969 FKTP yang telah bekerjasama dengan JKN (BPJS kesehatan), dan pada tahun 2016 ada sebanyak 80,708 FKTP yang telah bekerjasama dengan JKN (BPJS kesehatan) (Kurniawan, Mustika, Muhammad, \& Putri, 2019).

Semakin meningkatkan jumlah peserta BPJS tentunya dibutuhkan sebuah sistem informasi yang dapat menunjang pelayanan di sebuah fasilitas kesehatan, sehingga pada tahun 2014 BPJS mengeluarkan sistem informasi yang bernama aplikasi Pcare untuk pelayanan kesehatan pertama. Klinik Dr.Alfred telah bekerja sama dengan BPJS kesehatan dalam melayani pasien, sehingga untuk masyarakat yang ingin berobat di Klinik Dr.Alfred dapat menggunakan BPJS kesehatan. Pasien yang berkunjung berobat di klinik Dr.alfred dalam satu hari mencapai 150-200 pasien perhari yang terdiri dari pasien BPJS, pasien Umum dan pasien USG kehamilan sehingga dibutuhkan pelayanan yang cepat dan bermutu. Tujuan penelitian ini adalah Evaluasi Implementasi Aplikasi Primary Care (Pcare) Guna Menunjang Pengklaiman BPJS di Klinik Dr.Alfred

Klinik Dr.Alfred dalam melayani pasien peserta BPJS menggunakan aplikasi Pcare. Selama menggunakan aplikasi ini belum pernah dilakukan Evaluasi untuk mengetahui kelemahan aplikasi Pcare apabila dilihat dari kinerja, control, dan efisensi berdasarkan hasil studi pendahuluan yang dilakukan di Klinik Dr.Alfred.

\section{METODE PENELITIAN}

Jenis penelitian yang digunakan dalam penelitian ini menggunakan metode kualitatif dengan pendekatan deskriptif, dan menggunakan rancangan penelitian studi kasus. Menurut (Azwar, 2014) penelitian desktiptif adalah penelitian yang bertujuan untuk menggambarkan secara sistematik, akurat fakta dan karakteristik mengenai populasi dan bidang tertentu.

Evaluasi Implementasi Aplikasi Primarycare (Pcare) Guna Menunjang Pengklaiman BPJS di Klinik Dr. Alfred Majalaya 
Sedangkan penelitian dengan pendekatan kualitatif lebih menekankan analisisnya pada proses penyimpulan deduktif dan induktif serta pada analisis terhadap dinamika hubungan antar fenomena yang diamati, dengan menggunakan logika ilmiah. Penelitian ini dilaksanakan selama 3 bulan terhitung mulai Bulan April 2021 sampai Juni 2021 yang dilakukan di Klinik Dr.Alfred Majalaya yang bertempatan di Jl.Babakan Majalaya Ruko Maris Square Kav 22 Kab. Bandung.

Informan penelitian atau yang sering disebut subjek penelitian adalah orang pada latar penelitian yang dimanfaatkan untuk memberikan informasi tentang situasi atau kondisi latar penelitian (Moleong, 2017). Subject yang diikutsertakan dalam penelitian ini diantaranya petugas rekam medis dan petugas Farmasi.

Menurut (Bachri, 2010) pengecekan data untuk memperoleh keyakinan terhadap kebenaran data pada penelitian kualitatif dapat dilakukan dengan triangulasi. Triangulasi adalah suatu pendekatan analisa data dengan cara membandingkan dan merangkum data dari berbagai sumber yang berbeda. Menurut (Creswell, 2015) ketika para peneliti kualitatif berusaha menemukan bukti untuk mendokumentasikan kode atau tema dalam beragam sumber data, mereka sebenarnya sedang mentriangulasi informasi dan menyediakan Validitas bagi temuan mereka.

Validasi data dalam penelitian ini menggunakan triangulasi sumber dan teknik, dimana triangulasi sumber membandingkan hasil wawancara petugas Rekam medis, dan petugas Farmasi dengan hasil wawancara kepada kepala Klinik Dr.Alfred Majalaya sedangkan triangulasi teknik adalah membandingkan hasil wawancara dengan hasil observasi peneliti.

\section{HASIL DAN PEMBAHASAN}

\section{A. Hasil Penelitian}

\section{Kinerja Aplikasi Pcare di Klinik Dr.Alfred Majalaya}

Berdasarkan hasil penelitian yang telah dilakukan di Klinik Dr.Alfred Majalaya menunjukan bahwa aplikasi Pcare yang digunakan di Klinik dr. Alfred Majalaya masih sering mengalami error dan loading lama. Hal tersebut dapat dibuktikan dengan hasil wawancara yang dilakukan pada pengguna hasil Pcare di Klinik Dr.Alfred Majalaya. Berdasarkan rekapitulasi hasil wawancara yang peneliti lakukan kepada 4 respondens pengguna aplikasi pcare di Klinik Dr.Alfred Majalaya menunjukan ada sebanyak 4 respondens atau 100\% yang menyatakan aplikasi Pcare di Klinik Dr.Alfred Majalaya sering mengalami error dan loading lama.

\section{Pengendalian aplikasi pcare di Klinik Dr.Alfred Majalaya}

Berdasarkan hasil penelitian yang telah dilakukan di Klinik Dr.Alfred Majalaya terkait pengendalian (control) aplikasi Pcare menunjukan bahwa masih ada petugas yang tidak berwenang yang dapat mengakses dan menggunakan aplikasi Pcare di Klinik dr.alfred Majalaya. Hal tersebut dapat dibuktikan dengan rekapitulasi hasil wawancara yang menunjukan ada sebanyak 4 respondens atau $100 \%$ menyatakan terdapat selain petugas yang berwenang yang dapat mengakses dan menggunakan aplikasi Pcare di masing - masing bagian.

Berdasarkan hasil penelitian terdapat sistem keamanan yang dipasang di aplikasi Pcare yaitu dengan cara harus menginput username dan password sebelum menggunakan aplikasi Pcare. Hal tersebut dapat dibuktikan dengan rekapitulasi hasil wawancara yang dilakukan dengan 4 respondens menunjukan 
bahwa terdapat 4 respondens atau $100 \%$ yang menyatakan terdapat sistem keamanan yang dipasang di komputer.

Berdasarkan hasil penelitian terdapat sistem keamanan yang dipasang di komputer klinik Dr.Alfred Majalaya, dimana fungsi dari sistem keamanan ini adalah untuk memproteksi dari virus dan juga hacker. Hal tersebut dapat dibuktikan dengan rekapitulasi hasil wawancara menunjukan bahwa terdapat 2 respondens atau 50\% yang menyatakan komputer yang ada di Klinik Dr.Alfred Majalaya telah terpasang alat keamanan khusus untuk antivirus dan anti hacker, dan terdapat 2 respondens yang menyatakan ada komputer di Klinik Dr.Alfred Majalaya yang belum terpasang alat pengamanan khusus untuk antivirus dan anti hacker.

\section{Efisiensi penggunaan aplikasi primary care (Pcare) di Klinik Dr.Alfred Majalaya}

Berdasarkan hasil penelitian yang telah dilakukan di Klinik Dr.Alfred Majalaya menunjukan bahwa penggunaan dan pemanfaatan sumber daya (manusia dan material) yang ada sudah sesuai dengan kebutuhan. Hal tersebut dapat dibuktikan dengan rekapitulasi hasil wawancara yang peneliti lakukan kepada 2 respondens. Ada sebanyak 1 respondens atau 50\% menyatakan jumlah sumber daya manusia, perangkat keras, dan sistem informasinya sudah sesuai dengan kebutuhan, dan ada sebanyak 1 respondens atau 50\%.

\section{B. Pembahasan}

Berdasarkan hasil penelitian menunjukan pengguna tidak pernah melakukan input berulang kali pada aplikasi Pcare. Hal tersebut dapat dibuktikan dengan rekapitulasi hasil wawancara yang telah peneliti lakukan kepada 2 respondens sebagai pengguna aplikasi Pcare menunjukan ada sebanyak 2 responden atau $100 \%$ yang menyatakan tidak ada petugas menyatakan input berulang kali.

\section{Kinerja aplikasi Pcare di Klinik Dr.Alfred Majalaya}

Terdapat 4 respondens yang menyatakan aplikasi Pcare di Klinik Dr.Alfred Majalaya sering mengalami error dan loading lama, hal tersebut dikarenakan aplikasi Pcare sering mengalami maintenance sehingga ikut mempengaruhi kinerja aplikasi Pcare, spesifikasi komputer yang ada di Klinik Dr.Alfred Majalaya belum sesuai dengan standar yang telah ditetapkan oleh pihak BPJS, sehingga kendala aplikasi error dan loading lama sering terjadi. Hal tersebut tidak sesuai dengan (KepMenKes, 2011) No.1171/Menkes/III/2011 tentang sistem informasi rumah sakit dan menurut Cahyaningrum (2015) yang menyatakan maksud dan tujuan SIMPUS salah satunya adalah membantu kelancaran administrasi dan manajemen puskesmas dalam menyimpan dan transmisi data untuk penyusunan laporan mengenai kesehatan di puskesmas masing masing (Cahyaningrum, 2015).

\section{Pengendalian aplikasi pcare di Klinik Dr.Alfred Majalaya}

Komputer dan aplikasi pcare yang ada di Klnik Dr.Alfred Majalaya telah terpasang sistem pengamanan khusus diantaranya menggunakan username dan juga password sebelum masuk kedalam sistem aplikasi Pcare dan telah terinstal antivirus dan juga anti hacker yang ada di komputer Klink Dr.Alfred Majalaya. Akan tetapi berdasarkan hasil penelitian yang telah dilakukan di klinik Dr.Alfred Majalaya menunjukkan sebanyak 4 respondens atau $100 \%$ menyatakan terdapat selain petugas yang berwenang yang dapat mengakses dan menggunakan aplikasi Primary care di masing - masing bagian. Hal tersebut tidak sesuai dengan (Jogiyanto, 2011).

\section{Evaluasi Implementasi Aplikasi Primarycare (Pcare) Guna Menunjang Pengklaiman} BPJS di Klinik Dr. Alfred Majalaya 


\section{Efisiensi pengguna aplikasi pcare di Klinik Dr.Alfred Majalaya}

Menurut hasil penelitian yang dilakukan oleh krishnan (2010) ada beberapa keunggulan apabila menggunakan sistem informasi manajemen kesehatan diantaranya adalah meningkatkan efektifitas, efisiensi, menghemat sumber daya, kerangka kerja yang fleksibel, menghemat waktu petugas dalam pencatatan dan pembuatan laporan, dan dapat dipulihkan dalam waktu 2 tahun apabila sistem sudah beroperasi penuh(Krishnan, Nongkynrih, Yadav, Singh, \& Gupta, 2010).

Terdapat 2 respondens atau $50 \%$ menyatakan antara jumlah sumber daya manusia, perangkat keras, dan sistem informasi belum sesuai dengan kebutuhan. Hal tersebut dikarenakan antara jumlah pasien yang datang berobat dengan jumlah komputer dan sumber daya yang ada masih belum mencukupi, sehingga pekerjaan yang dilakukan petugas menjadi semakin berat dan lebih banyak (Bata, Arifin, \& Darmawansyah, 2013).

Menurut (Nyamtema, 2010) berbagai faktor terkait tidak efisien dan efektifnya sistem informasi manajemen kesehatan di Tanzania adalah kurangnya pemahaman yang jelas terhadap tujuan, pengguna dan pola aliran data kesehatan koleksi dikaitkan dengan kualitas pengumpulan data yang buruk. Menurut (Kurniawan et al., 2019) ada beberapa faktor yang mempengaruhi kualitas data diantaranya adalah kendala desain operasional dalam organisasi kerja di setiap arus informasi, mulai dari pengumpulan, pengolahan, pelaporan, dan analisis data, kapasitas untuk menggunakan informasi tertinggal, kurangnya sumber daya manusia, komputer dan keterampilan entry data.

\section{KESIMPULAN}

Kinerja aplikasi Pcare di Klinik Dr.Alfred Majalaya masih sering mengalami error dan loading lama. Cara pengendalian (control) Pcare di Klinik Dr.Alfred Majalaya menggunakan user name, password, antivirus dan anti hacker. Adanya petugas yang tidak mempunyai wewenang yang dapat mengakses dan menggunakan aplikasi Pcare. Siapa pun aspti kesal, ketika banyak pasien BPJS sementara aplikasi pcare error dan tidak bisa login. Sebenarnya ada beberapa faktor yang menyebabkan aplikasi pcare bpjs error dan saat aplikasi pcare bpjs error maka ada keterangan username dan password salah sementara username dan password pcare bpjs sudah benar. Aplikasi Pcare bpjs sedang gangguan, ada update aplikasi Pcare bpjs, terlalu banyak yang login di perangkat aplikasi Pcare bpjs, untuk mengatasi kesulitan log in tersebut cukup dengan menghilangkan huruf "s" dalam "https" di alamat pcare tersebut di atas, sehingga menjadi "http://pcare.bpjs-kesehatan.go.id" (tanpa tanda kutip ). Pastikan tidak ada huruf "s" pada "http"-nya. (kalau perlu silahkan di klik alamat tersebut untuk masuk ke aplikasi Pcare), merubah alamat web aplikasi pcare bpjs yang tadinya https://pcare.bpjs-kesehatan.co.id menjadi https://pcare.bpjskesehatan/eclaim/login maka aplikasi pcare bpjs akan normal kembali dan bisa login seperti biasa.

\section{BIBLIOGRAFI}

Azwar, Saifuddin. (2014). Metode Penelitian, Yogyakarta: Pustaka Pelajar, 2012. Reliabilitas Dan Validitas Edisi, 4.

Bachri, Bachtiar S. (2010). Meyakinkan validitas data melalui triangulasi pada penelitian kualitatif. Jurnal Teknologi Pendidikan, 10(1), 46-62.

Bata, Yuristi Winda, Arifin, M. A., \& Darmawansyah, A. (2013). Hubungan Kualitas Pelayanan Kesehatan dengan Kepuasan Pasien Pengguna Akses Sosial pada Pelayanan Rawat Inap di RSUD Lakipadada Kabupaten Tana Toraja Tahun 2013. 
Makasar, Univeritas Hasanuddin.

Cahyaningrum, N. (2015). Analisis Pelaksanaan Sistem Informasi Manajemen Puskesmas (SIMPUS) di UPTD Puskesmas Penumping Kota Surakarta. Surakarta: Apikes Citra Medika Surakarta.

Creswell, John W. (2015). Penelitian kualitatif \& desain riset. Yogyakarta: Pustaka Pelajar.

Jogiyanto, H. M. (2011). Pengenalan Komputer, Dasar Ilmu Komputer, Pemrograman. Salemba Empat: Yokyakarta.

KepMenKes, R. I. (2011). Juknis SIRS 2011 (Sistem Informasi Rumah Sakit). Jakarta: KepMenKes RI.

Krishnan, Anand, Nongkynrih, Baridalyne, Yadav, Kapil, Singh, Satyavir, \& Gupta, Vivek. (2010). Evaluation of computerized health management information system for primary health care in rural India. BMC Health Services Research, 10(1), 1-13.

Kurniawan, Agung, Mustika, Denny Adrian, Muhammad, Rizal Chandra, \& Putri, Susanti Catur. (2019). Evaluasi Implementasi Aplikasi Primary Care (Pcare) di Klinik Laras Hati. Jurnal Kesehatan Vokasional, 4(1), 21-26.

Moleong, Lexy J. (2017). Metodogi Penelitian Kualitatif. Bandung: PT Remaja Rosda Karya.

Nyamtema, Angelo S. (2010). Bridging the gaps in the Health Management Information System in the context of a changing health sector. BMC Medical Informatics and Decision Making, 10(1), 1-6.

Perundang-udangan, B. Peraturan. (1945). Undang-Undang Negara Republik Indonesia Tahun 1945. Undang-Undang Nomor, 4, 1-2.

Suprianto, Arip, \& Mutiarin, Dyah. (2017). Evaluasi Pelaksanaan Jaminan Kesehatan Nasional. Journal of Governance and Public Policy, 4(1), 71-107.

Susanti, Ari Indra, Rinawan, Fedri Ruluwedrata, \& Amelia, Indah. (2019). Penggunaan Mobile Apps Kesehatan oleh Kader Pada Anjungan Mandiri Posyandu (AMP) Di Kecamatan Pasawahan, Purwakarta. Jurnal Kesehatan Vokasional, 4(1), 27-31.

Wariyanti, Astri Sri, Suryono, Arief, \& Indarto, Dono. (2016). Evaluation of the Management Information System at the Primary Health Care in the National Health Insurance Program in Surakarta. Journal of Health Policy and Management, 1(1), 5360.

(C) 2021 by the authors. Submitted for possible open access publication under the terms and conditions of the Creative Commons Attribution (CC BY SA) license (https://creativecommons.org/licenses/by-sa/4.0/). 